\title{
Improved Exchange Rate Farmers through Rice Falied Crop Intensification in Tolitoli, Indonesia
}

\author{
Nursida K. Bantilan ${ }^{1}$, Made Antara Wahyuningsih ${ }^{1} \&$ Rustam Abd Rauf ${ }^{1}$ \\ ${ }^{1}$ Department of Agriculture, Tadulako University, Palu, 94118, Indonesia \\ Correspondence: Nursida K. Bantilan, Department of Agriculture, Tadulako University, Palu, 94118, Indonesia. \\ E-mail: nursidahbantilan@yahoo.com
}

Received: August 14, 2017 Accepted: October 5, $2017 \quad$ Online Published: October 8, 2017
doi:10.5539/sar.v7n1p1
URL: https://doi.org/10.5539/sar.v7n1p1

\begin{abstract}
Farmer Trade Rate (NTP) is a price comparison received by farmers at the price paid by farmers, which is one indicator measure the welfare of farmers. The analysis of NTP research, has been conducted (Budi, 2015; BPS, 2013; Simatupang, 2007; Mokuwa, 2013; Jhung Ahn, 2016) note that low NTP is affected by production, household consumption, Selling of rice and the use of superior seeds. Despite efforts to improve NTP has not been done, so too In Tolitoli. The result is difficult to know the level of farmers' welfare in terms of the size of NTP obtained by farmers. So to increase the NTP used agricultural intensification by using organic fertilizer, which can increase NTP. The purpose to know the factors that affect (NTP), the magnitude of the increase in NTP improve the welfare of farmers, and comparisons of NTP users of organic and inorganic fertilizers. This study uses primary data obtained from farmers through direct interviews using a prepared list of questions. Farmer of respondents was taken by using slovin method so that determined big sample of rice farmer farmer as many as 117 people apply intensification by using organic fertilizer. The data were analyzed using multiple linear regression analysis. The result of the research showed that the influence of NTP, the Food Consumption Exchange Rate (NTKP) and the Production Factor Exchange Rate (NTFP) contributed 86.7\% and significantly to the increase of NTP. Increased NTP of Organic Fertilizer has implication to farmer's prosperity. Organic fertilizer users obtain higher NTP than inorganic fertilizer users. Can be concluded intensification system by using organic fertilizer can increase NTP.
\end{abstract}

Keywords: farmers exchange rate, organic fertilizer

\section{Introduction}

The agricultural sector is one of the sectors or business fields supporting the Indonesian economy. Based on the results of the agriculture census (ST) 2013 by the Central Bureau of Statistics (BPS, 2013) noted that the contribution of the agricultural sector over the past ten years declined and ranked third after the manufacturing and trade, hotel and restaurant sector. In the national development, the role of the agricultural sector is, among other things, the provision of basic food needs, the formation of foreign exchange (through exports), and the reservoir of labor, especially in rural areas.

Central / national agricultural development targets: achieving self-sufficiency in food and sustainable self-sufficiency, increasing food diversification, increasing value added, competitiveness, exporting, and improving farmer's welfare. The wetland rice sector is a sector that determines the economy in Indonesia as well as in Tolitoli District, since most have livelihoods by farming (regional profile of Tolitoli District, 2014). Government policy in improving the welfare of farmers has a very strategic meaning. One measure of farmers 'purchasing power that reflects farmers' welfare level, published by the Central Bureau of Statistics (BPS) and formulated in the Farmers Exchange Rate (NTP), the NTP index is one of the indicators used to measure the exchange rate of products sold by farmers Products needed by farmers in production and consume goods and services for household purposes. NTP has double impact (Supriyati, Saptana, \& Sumedi, 2001) not only in increasing the participation of farmers and production in stimulating the rural economy, creating rural employment and growing demand for non-agricultural products; But also expected to reduce the difference (create balance) of development between regions (rural-urban), as well as between regions and the optimization of national resources. Efforts to increase the NTP has been done by the central government and local governments through fertilizer subsidies, counseling, and also the provision of capital. But all that can not 
increase the NTP as expected.

The orientation of agricultural development towards improving the welfare of farmers, it is very relevant to assess the exchange rate of farmers (NTP) as one indicator of farmers' welfare level and state of the rural economy and improvement efforts NTP. (Setiani, et al, 2007). Farmers Exchange Rate (NTP) is interpreted as a marker (indicator) of farmers' welfare. The concept of NTP measurement is very simple, measured as the ratio of the received price index and the price index paid by farmers, making it easy for the general public to understand. NTP is equal to the comparison of the price index received by the farmer with the price index paid by the farmer means the index received by the farmer with the price index paid by the farmer in the rural area (ib). The NTP relationship with the farmer's welfare level as a producer is clearly visible in the position (it) which is on the numerator of the NTP number. If the price of agricultural products rises, assuming the production volume is not reduced, the income or income of farmers from the harvest will also increase. Price developments indicated that it is an indicator of the level of welfare of producer farmers from the income side.

Therefore, to see the level of welfare of farmers as a whole also need to see the other side of the development of the amount of expenditure / expenditure, both for consumption and production needs, farmers as producers and also as consumers faced with the choice of allocating income, the first to meet basic needs (Consumption) for the survival of farmers and their families. Both expenditures for agricultural production are the livelihood fields that include the operational costs of production and investment and capital market formation. For this it is possible only if the basic needs of farmers have been met, thus investment and capital goods formation are the determining factors for farmers' welfare levels in terms of NTP.

NTP can be used as: (1) farmers 'welfare equipment, (2) farmers' purchasing power, (3) price determinants received and price determinants paid by farmers. A measure of the purchasing power of farmers at a glance can indicate that their welfare level is formulated in the form of Farmer Trade Value (NTP) formed by the complex interrelationship of a price-forming system, both the price received and the price paid by the farmer.

Farmers' welfare levels published by the Central Bureau of Statistics (BPS) are formulated in the Farmers Exchange (NTP). The term exchange rate actually has a broad meaning. In general, the exchange rate can be classified into four groups (Ruauw E 2010), namely: (a) Barter Terms of Trade, (b) Factorial Term of Trade, (c) (IncomeTerms of Trade) and (d) Farmers Term of Trade. (Setiani, et al, 2007)

Based on data from the Food and Horticulture Service Office of Tolitoli District.2015) NTP May 2015 was a decline for food crops, horticulture, and smallholder plantations. NTP food crops fell by 3.44 percent, a sharp drop in food crop NTP from 100.80 to 97.33 was due to a fall in the index received by the wetland rice farmer group. Furthermore, it is written that the time period between harvest and honey season (drought) becomes a transition period for farmers

Furthermore, in particular NTP food crops in Tolitoli District in November 2014 reached 98.71. This figure is still classified as having not reached the level of farmers' welfare (BPS, 2014), this is in line with the results of agricultural census (2013) that the contribution of the agricultural sector has decreased.

The study of NTP has been done in other regions even abroad, the increase of NTP is a marker of the welfare of farmers, but the increase of NTP by using organic fertilizer has never been done. So that the intensification of agriculture by using organic fertilizer made an option to improve the NTP, because most people in Tolitoli district is an agrarian society based on the agricultural sector. So need to study in depth about the factors that affect NTP, the increase of NTP with the incentives using organic fertilizers, and know the difference NTP users of organic and inorganic fertilizers in Tolitoli District.

\section{Method}

The research was conducted in Tolitoli District consisting of 3 subdistricts, Galang Subdistrict, Tolitoli Utara Subdistrict and Dampal Selatan District. The three districts are chosen because it is the center of rice field production in Tolitoli district, the geographical location of the three districts respectively, South Dampal is adjacent to Donggala Regency, North Tolitoli is adjacent to Buol Regency, and Galang District is located in the center of Tolitoli district. This research is planned to be carried out in the planting season of 2015 - 2016 for 3 times the harvest season

The population of 4600 rice farmers either using organic or non-organic fertilizer. Respondents who will be sampled as many as 117 people for rice farmers (given treatment by using organic fertilizer) and 117 rice farmers who use an-organic fertilizer, sampling using the formula Slovin (Asnawi, 2014), as follows: 


$$
n=\frac{N}{1+N e^{2}}
$$

where:

$\mathrm{n}$ : number of samples

$\mathrm{N}$ : number of population

e: limit tolerance of error (error tolerance)

In this sampling set the limit tolerance of error (error tolerance) of $0.15(\mathrm{e}=15 \%)$ for each district area. This study uses primary data obtained from direct interviews of respondents and secondary data obtained from other supporting literature. Data in this research is obtained through questionnaires, interviews, observation / observation and documentation and secondary data available in farmer groups. Observation on the production process is used to match the truth of data that has been given or obtained previously. Documentation is performed to obtain an overview of the general conditions during the production process in accordance with the provisions of the farm sapta selected as the sample.

The analysis used in this research is panel data regression method. By using cross section dummy variable (dummy region) which become research sample to know factor influencing to NTP. If NTP $<100$ decreases, NTP $=100$ breaks, NTP $>100$ surplus.

Estimate the relationship of one dependent variable with two independent variables with the general formula:

$$
\mathrm{Y}=a+\mathrm{bD}_{\mathrm{i}}+\mathrm{e}
$$

Reprinted with twelve independent variables as follows:

$$
\mathrm{Y}=a_{0}+\mathrm{b}_{1} \mathrm{X}_{1}+\mathrm{b}_{2} \mathrm{X}_{2} \mathrm{D}
$$

where:

Y: Farmers Exchange Rate

$\mathrm{X}_{1}$ : Food Consumption Exchange Rate (NTKP)

$\mathrm{X}_{2}$ : Production Factor Exchange Rate (NTFP)

Farmers exchange value is obtained by the formula:

$$
\mathrm{NTP}=(\mathrm{HT} / \mathrm{HB}) \mathrm{X} 100
$$

where:

$\mathrm{HT}=$ Price index received by farmers

$\mathrm{HB}=$ price index paid by farmers

\section{Results and Discussion}

Based on the results of secondary data, farmers in Tolitoli district are grouped based on the ability of the farmer group, the division of farmers group ability class at 1 January 2016 data from the Office of Food Crops and Horticulture from 10 districts. The division, namely, beginners as many as 948 groups, further 232 groups, 25 groups of madya, and the main does not exist in Tolitoli district. The number of farmers in Tolitoli district is 26.283 with 91 gapoktan groups. Based on the results obtained through interviews, observation, documentation and spreading of questionnaires to the research subjects in North Tolitoli sub-district as many as 34 people, Galang 43 people, and South Dampal 40 peasants with the number of subjects 234 people, 117 people using organic fertilizer and 117 User of an-organic fertilizer. The results of interviews and data analysis obtained information factors that affect the NTP which has implications on the welfare of farmers. The influential factors are: (1) The exchange rate of the factors of production (NTFP), (2) The consumption exchange rate (NTKP) which consists of food consumption, and non-food consumption, together affects the increase of NTP. This is in line with the results of Rudi's research, 2011 in West Kalimantan which concluded that one of the facto which affects NTP is non-food consumption consisting of board, clothing, health and education costs. In contrast to Ginting, Ginting R., \& Lubis (2013) write that the factors that affect the NTP in Deli serdang is the low price received by farmers.

The result of the analysis shows that by applying the system of intensification of organic fertilizer use can increase Farmers Exchange Rate (NTP). With the increase of NTP has implications for the welfare of farmers. This is in line with opinion of Elizabeth \& Darwis (2000) that the increase in NTP can improve the welfare of farmers in East Java. This is confirmed by Ikin Sadikin, 2008 which states that, one indicator of farmers' welfare 
is the high NTP. The result of analysis shows that the NTP value of organic fertilizer users in each sub-district varies, the average of NTP in North Tolitoli subdistrict is 117.6, Galang 118.3 and South Dampal 115,9. The average acquisition of NTP users of organic fertilizer in Tolitoli district is 117.3. While NTP users of anorganic fertilizers dikecamatan Tolitoli Utara 114.3, Galang 112.1, and South Dampal 113.8. The average yield of NTP inorganic fertilizer users was 113.4. As seen in the following table (table 1) and diagram (Figure 1).

Table 1. Farmers Exchange Rate

\begin{tabular}{lll}
\hline sub-district & An-organic & Organic \\
\hline Tolitoli Utara & 114,2 & 117,6 \\
Galang & 112,1 & 118,3 \\
Dampal Selatan & 113,8 & 115,9 \\
Mean & 113,4 & 117,3 \\
\hline
\end{tabular}

Based on the result of regression test, the amount of organic fertilizer contribution in the increase of NTP in Tolitoli district has a positive effect with the contribution of $86.7 \%$ dependent variable (NTP) influenced by independent variable (Production Factor Exchange Rate (NTFP) and Food Consumption Exchange Rate (NTKP ), Meaning that production factors, food consumption and non-food consumption are closely related to the increase of NTP, compared to previous studies conducted by Prabawati that contribute to the increase of NTP in West Sumatra due to high wage during one harvest season and low production.

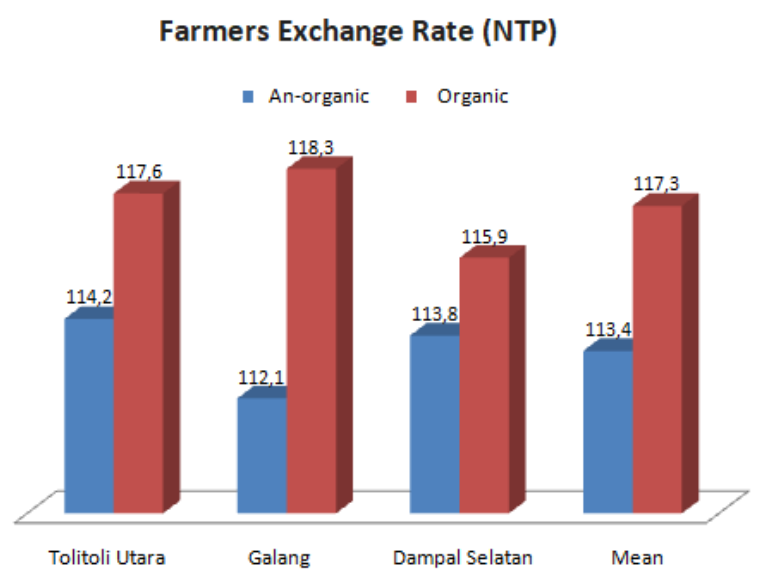

Figure 1. Different Value of NTP (An-organic and Organic)

The results of the analysis also show that there is a significant difference between organic and inorganic fertilizer users in Tolitoli district. What is seen from the average NTP users of organic fertilizer is 117.3 and the average of anorganic fertilizer users is 113.4. The difference between organic and inorganic fertilizer users in Tolitoli district is 3.90 percent, the use of organic fertilizer can increase the exchange rate of farmers (NTP) in Tolitoli district, the high NTP can affect the welfare of rice farmers in Tolitoli district. This is in line with the results of previous research conducted by Ginting et al (2013), Ruauw (2010), Unnevehr, Juliano, \& Perez, C. M. (2001), Budi et al. (2015), inferred that farming activities have a goal to increase productivity in order to gain higher profits. Production and productivity can not be separated from the factors of production owned by farmers to increase production of their crops (Asnawi, 2014).

Based on the results of interviews with farmers, the selling price of organic fertilizer products is higher when compared to the selling price of an-organic rice, for rice price. During April 2015, the price of low quality grain at the farmers' level is Rp 3.59224 per kilogram. This decreased by 7.39 percent compared to the previous month. While in grain milling valued only Rp 3,670.00 per kilogram or down 7.17 percent over the previous period. (Budi, 2015).

The exchange rate of Central Sulawesi farmers in the last three years still stands below 100 percent. BPS (2015) Central Sulawesi Farmer's Trade Values (NTP) during August 2015 amounted to 97.71 percent, down 0.51 percent compared to the previous month's NTP. This is due to the decrease of NTP food crop sub-sector by 1.06 percent. The farmer's price index fell 0.55 percent, while the price index paid by farmers (ib) fell 0.05 percent. 
In general, food expenditure is still greater than non-food in Tolitoli district. This is different from the results of research Rahmad (2001) factors that affect the non-food consumption factor NTP. However, with the increase of NTP, it can be interpreted to improve the prosperity of farmers using organic fertilizer in Tolitoli district.

\section{Conclusion}

Factors influencing the increase of farmer's exchange rate (NTP) are produced production, food consumption factor, and non-consumption factor, and the use of fertilizer The amount of significant influence of organic fertilizer use is $86,7 \%$ with significant value $0.00<0.05$. Factors affecting the welfare of farmers is the price paid by farmers and high production costs are not directly proportional to the price received by farmers, through farmers sapta intesifikasi in this case using organic fertilizer can increase the exchange rate of farmers that have implications for improving the welfare of farmers. From this result, we suggestion that the need for counseling and socialization to farmers to utilize organic fertilizer as an alternative to increase rice paddy NTP as well as to improve the welfare of farmers in Tolitoli district.

\section{References}

Asnawi, R. (2017). Peningkatan produktivitas dan pendapatan petani melalui penerapan model pengelolaan tanaman terpadu padi sawah di Kabupaten Pesawaran, Lampung. Jurnal Penelitian Pertanian Terapan, $14(1)$.

Aulia. (2016). Analisis NTP dan angka harapan Hidup di Sumatera Utara. Journal Agroekonomi, 16(1).

Badan Pusat Statistik. (2013). Indikator pembangunan Ekonomi daerah kabupaten Tolitoli. Palu

Badan Pusat Statistik. (2014). Indikator pembangunan Ekonomi daerah kabupaten Tolitoli. Palu

Badan Pusat Statistik. (2015). Provinsi Sulawesi Tengah dalam Angka. Palu.

Badan Pusat Statistik Nasional. (2017).

Budi, (2015). Nilai Tukar Petani, SPI minta Impor Beras Dihentikan. Berita Bisnis. Bandung.

Direktorat Pangan Dan Pertanian, (2013). Studi Pendahuluan Rencana Pembangunan jangka Menengah Nasional (RPJMN) Bidang pangan Dan Pertanian 2015-2019. Kementerian Perencanaan Pembangunan Nasional/Badan Perencanaan Pembangunan nasional.

Dinas Tanaman Pangan dan Holtikultur Kab. Tolitoli, (2016). Laporan Akhir Analisis Nilai Tukar Petani Padi sawah di Kabupaten Tolitoli.: Palu. Dinas Tanaman Pangan Dan Hortikultura Kab. Tolitoli. Prov Sulawesi Tengah

Dwidjono H. Darwanto. (2005). Ketahanan Pangan Berbasis Produksi dan Kesejahteraan Petani. Ilmu Pertanian 12(2), 152-164, Fakultas Pertanian UGM dan MMA-UGM. Yogyakarta

Elizabeth, R., \& Darwis, V. (2000). Peran Nilai Tukar Petani dan Nilai Tukar Komoditas Dalam Upaya Peningkatan Kesejahteraan Petani Kedelai (Studi Kasus: Propinsi Jawa Timur). SOCA (Socio-Economic of Agriculturre and Agribusiness), 6(1).

Ginting, M. S., Ginting, R., \& Lubis, S. N. (2014). Faktor-Faktor yang Mempengaruhi Nilai Tukar Petani Ubi Kayu (Studi Kasus: Desa Tadukan Raga, Kecamatan STM Hilir, Kabupaten Deli Serdang, Provinsi Sumatera Utara). Journal on Social Economic of Agriculture and Agribusiness, 3(3).

Ikin Sadikin dkk, (2008) Kinerja beberapa indikator kesejahteraan petani padi dipedesaan Kabupaten Kerawang. BPTP Jawa Barat. Jurnal Iptek Tanaman Pangan, 6(2).

Jhun Ahn Chun, et al., (2016). Assessing rice productivity and adaptation strategies for Southeast Asia under climate change through multi-scale crop modeling. Journal Agricultural Systems, 143, 14-21. https://doi.org/10.1016/j.agsy.2015.12.001

Rachmad (2001). Analisis Nilai Tukar Petani Indonesia. Journal Litbang Pertanian Manado.

Ruauw, E. (2010). Nilai Tukar Petani Sebagai Indikator Kesejahteraan, Petani jurnal ase, 6(2), 1-8.

Rudi. (2011). Nilai tukar petani dan faktor-faktor yang mempengaruhi di sentra produksi jagung Kalimantan Barat. Journal Litbang Kalimantan Barat, 2(3).

Setiani, et al., (2007). Kontribusi Teknologi Usaha tani dan Aprestasi Pasar Terhadap Nilai Tukar Petani Di Wilayah Miskin.

Supriyati, Saptana, \& Sumedi. (2001). Dinamika ketenagakerjaan dan penyerapan tenaga kerja di pedesaan jawa (kasus di propinsi Jawa Barat, Jawa Tengah dan jawa timur). Pusat Penelitian dan Pengembangan Sosial 
Ekonomi Pertanian, Bogor Badan Penelitian dan Pengembangan Pertanian, Departemen Pertanian RI.

Syam, M. (2008). Padi Organik dan Tuntutan Peningkatan Produksi Beras. Jurnal Imtek Tanaman pangan, 3(1).

Talpur Mokuwa, et al., (2013) A review on the enhancement of rice production in paddy field with minimum input of water. Journal African Journal of Agricultural Research, 6(3).

Unnevehr, L. J., Juliano, B. O. dan Perez, C. M. (2001). Consumers demand for rice grain quality in Southheast Asia. In Rice Grain Quality and Marketing. Papers presented at the International Rice Research Conference. International Rice Research Institute. Philippines. 15-23.

\section{Copyrights}

Copyright for this article is retained by the author(s), with first publication rights granted to the journal.

This is an open-access article distributed under the terms and conditions of the Creative Commons Attribution license (http://creativecommons.org/licenses/by/3.0/). 